\title{
RESEARCH OF INDICATOR ANALYSIS OF SOCIAL AND ECONOMIC SECURITY
}

\author{
CShvaiba D., ORCID: 0000-0001-6783-9765, Ph.D., Belarusian Trade Union \\ of Workers of Chemical, Mining and Oil Industries; Belarusian National Technical University, \\ Minsk,Belarus,shvabia@tut.by
}

\section{ИССЛЕДОВАНИЕ ИНДИКАТОРНОГО АНАЛИЗА СОЦИАЛЬНО-ЭКОНОМИЧЕСКОЙ БЕЗОПАСНОСТИ}

СШвайба Д. Н., ORCID: 0000-0001-6783-9765, канд. экон. наук, Белорусский профсоюз работников химической, горной и нефтяной отраслей промышленности; Белорусский национальный технический университет, г. Минск, Беларусь

Abstract. The thresholds represent the subsequent specification of the state interests in the field of socio-economic security risks. They say these aspects of socio-economic security of food, energy, infrastructure, technology, etc. To a significant extent there are recognized difficulties of life support. In this group are required to enter threshold values, characterizing the danger, located on the border between socio-economic and other characteristics of a security, for example, demographic, industrial security, available strategic reserves etc. The more difficult is the question of the quantitative parameters of threshold values. It must be said that the development of methodological approaches to the determination of such quantitative characteristics has proved to be a difficult task, taking into account that there is a very strict criticism about the quantitative characteristics of the thresholds. It is possible to agree with such arguments against the quantitative calculation of thresholds as their lack of real-specific orientation, the controversy of the methods of calculation used, etc.at the same time, the threshold indicators are a real signal of a positive or negative position, a team to the action of the relevant state bodies.

Аннотация. Пороговые показатели представляют последующую детализацию государственных интересов в области опасностей социально-экономической безопасности. Они характеризуют такие стороны социально-экономической безопасности, как продовольственная, топливно-энергетическая, инфраструктурная, технологическая и т. д. В значимой мере тут отражаются трудности жизнеобеспечения. В данную группу обязаны войти пороговые показатели, характеризующие опасности, находящиеся на границе между социально-экономической и другими характеристиками защищенности, к примеру, демографическая, промышленная защищенность, имеющиеся стратегические запасы и др. Тем более трудным считается вопрос о количественных параметрах пороговых значений. Нужно сказать, что выработка методических подходов к определению таких количественных характеристик оказалась трудной задачей, беря во внимание, что присутствует очень строгая критика по поводу количественных характеристик пороговых значений. Возможно согласиться с такими аргументами против количественного расчета пороговых значений как их недостаточная реально-конкретная ориентация, спорность применяемых способов расчета и др. При этом пороговые показатели - настоящий сигнал о позитивном или негативном положении, команда к действию соответствующих госорганов.

Keywords: security, socio-economic security, state, society, economic entity, employee, threat, interests, economy, analysis, system, perspective. 
Ключевые слова: защищенность, социально-экономическая безопасность, государство, общество, хозяйствующий субъект, работник, угроза, интересы, экономика, анализ, система, перспектива.

According to some researchers, a qualitative description of socio-economic security is considered important, especially since not all its interests and dangers can be fully disclosed quantitatively.

The thresholds represent the subsequent specification of the state interests in the field of socio-economic security risks. They say these aspects of socio-economic security of food, energy, infrastructure, technology, etc. To a significant extent there are recognized difficulties of life support.

This group must include threshold indicators characterizing the dangers located on the border between socio-economic and other characteristics of security, for example, demographic, industrial security, available strategic reserves, etc.

The more difficult is the question of quantitative threshold parameters. It must be said that the development of methodological approaches to the determination of such quantitative characteristics has proved to be a difficult task, taking into account that there is a very strict criticism about the quantitative characteristics of the thresholds.

It is possible to agree with such arguments against the quantitative calculation of thresholds as their lack of real-specific orientation, the controversy of the methods of calculation used, etc. at the same time, the threshold indicators are a real signal of a positive or negative position, a team to the action of the relevant state bodies.

It is necessary to identify some primary methodological approaches used in determining the quantitative characteristics of the threshold values.

1st. When determining a number of threshold values, not only calculation methods are widely used, but also methods of analogies, expert assessments, and goal setting.

2nd. The actual data at the moment for most of the characteristics are more negative than the threshold values we offer. But the important point should be that the thresholds cannot repeat the actual data. Otherwise, any sense is lost. Thresholds do not mean the beginning of the problem but show the threat zones.

3. Almost all thresholds were determined as a percentage of GDP. The threshold for the size of GDP itself has also been determined. While elementary to define the threshold in terms of GDP based on the characteristics of the standard of living of the population. So, for a significant group of threshold values according to the initial nature of the case was the performance on the standard of living of the population [1-2].

This is an indisputable advantage of the approaches currently used to resolve this difficulty, which necessitates the continuation of work in this direction.

Scientific and methodological justification for the formation of a list of threshold values may be the formulation of criteria, the requirements of which must meet this list. Threshold indicators of social and economic security are required:

-sufficiently holistic quantitative representation of the national interests of the state in the field of economy and possible threats to socio-economic security;

-reflect the essential rather than secondary features of these interests and the dangers of socio-economic security;

-to reflect the balance of the relationship and the interdependence between the thresholds, characterizing the various interests and dangers of socio-economic security;

-to ensure that the probability of intercountry and interregional comparisons; 
-comply with the country's statistical system.

When developing a system of characteristics, it is important to study the 1st nuance of the system formation. It is necessary to show the frequency of their development and presentation.

It makes sense to consider the development of differentiated lists of characteristics for the short and medium term. Short-term characteristics, in turn, must be divided into monthly, quarterly and annual. The composition of these lists will certainly not coincide, and in connection with this situation it will be necessary to propose a scheme of their interaction (the degree of concretization by individual vectors, periodicity, etc.). The resolution of these questions contains a direct relation to the creation of organizational informational base of research and requires in consequence of this particular development.

Another group of problems related to the organization of the study refers to the justification of the system of characteristics at the regional level. The characteristics monitored in the territorial context must be matched with the state-level indicators on the content and timing of the submission, and their list will appear to be much smaller, because not all the difficulties of the macro-level can be analyzed by territory. At the same time, the composition of regional characteristics may differ due to the different relevance and significance of individual regions, the presence of specificity in them.

To date, experience has been gained in the field of organization of 'security monitoring' in different economic sectors. However, this work is aimed only at the information nuance of security, and in practice there is a 'gap' between obtaining information about the dangers in certain areas and certain measures to neutralize them, which reduces the effectiveness of including good information support.

In this respect and are encouraged to begin exploring and developing advanced information technology security with their strong orientation to program-project response during the preparation of measures to decrease the risks of security. For this purpose, it is proposed to implement the scheme 'monitoring — program of neutralization of safety hazards', in which the stage of obtaining information is connected with the stage of the preparatory response to the identification of danger by the method of developing specific schemes, algorithms and programs (guidelines) of the upcoming actions.

With the formation of progressive information technology security of the real sector can be provided by the flow of data on the main reproductive areas of formation, covering:

-control and study of incoming data;

-active supervision of all parties to the current state of the economy;

-rapid and clear assessment, 'detection' of symptomatic symptoms in the real sector of emerging adverse events and trends;

-preliminary identification of ways to overcome the adverse effects on the economy.

At the same time, there must be a sufficient Arsenal of methods and tools (methodological support, resources, qualified personnel), the operational use of which will guarantee the return of the real sector, its individual parts and sectors of the economy to a state of equilibrium, subsequent progressive development.

Operational, elegant contour mood of the economy with the appearance in it of all kinds of 'disturbances' on the equilibrium mode of operation with the support of financial and economic regulators has the ability to be carried out by proven methods for pre-compiled methods and programs.

The study significantly simplifies the operational flexibility of the situation when the occurrence of such force majeure conditions, as suddenly emerging decline, financial and economic embargo, the inflation of import customs duties, strikes, natural disasters, major 
accidents, terrorist impact, the global influx of refugees, public perturbation etc. Thanks to the efficiency of obtaining and objectivity of the information and is likely immeasurably more rapid identification of the reasons of the distortions, gaps and prioritization of steps to normalize the situation.

In the methods of the program are required to be laid on a more frequent transmission of information, its specification and the changing nature of the offset the worse the situation agile methods. So, programs should be drawn up taking into account changes, if necessary, the priority resolution of the strategic problems of diversification of the profile of action.

In the program are required to be entered and parameters of the Directive that in case of emergency further transmitted to regional and state governments.

The introduction of the presented approach will make it possible to simplify the finding of active dependencies of interrelated socio-economic processes, their study as a consequence of the synthesis of various bases and at the same time as the prerequisites for many other phenomena and measures for the effective destruction of those that have negative results.

The presented block information and design system will provide a combination of aggregated characteristics of probable hazards with the development of predictive and model schemes of their destruction.

In General, the method of ensuring socio-economic security of the Republic of Belarus should include 7 blocks: theory and strategy of state security; national interests of Belarus in the field of economy; dangers in the sphere of economy; indicators of socio-economic security; threshold data indicators; organizational structure; legal provision of socio-economic security (Table).

Table.

ELEMENTS OF THE SOCIO-ECONOMIC SECURITY SYSTEM OF THE COUNTRY

\begin{tabular}{|c|c|c|c|c|}
\hline \multirow{2}{*}{$\begin{array}{c}\text { The concept of state } \\
\text { security }\end{array}$} & \multicolumn{4}{|c|}{ Socio-economic security } \\
\hline & threats & indicators & $\begin{array}{c}\text { Organization } \\
\text { al support } \\
\text { structures }\end{array}$ & $\begin{array}{c}\text { legal } \\
\text { support }\end{array}$ \\
\hline $\begin{array}{l}\text { Belarus in the global } \\
\text { community and its } \\
\text { constituent parts (global } \\
\text { security and geopolitical } \\
\text { role) } \\
\text { State interests of Belarus } \\
\text { Threats to state security } \\
\text { The security of the state }\end{array}$ & $\begin{array}{l}\text { Loss of production capacity due } \\
\text { to significant depreciation of fixed } \\
\text { assets } \\
\text { Public debt (domestic and } \\
\text { foreign)) } \\
\text { Debts of economic entities } \\
\text { High level of poverty } \\
\text { Capital flight } \\
\text { Low innovation and investment } \\
\text { activity } \\
\text { Inflation, including hidden and } \\
\text { expected price increases }\end{array}$ & $\begin{array}{l}\text { A total of } \\
150 \\
\text { indicators, } \\
\text { including } \\
19 \text { keys }\end{array}$ & $\begin{array}{l}\text { security } \\
\text { Council } \\
\text { State body } \\
\text { Regional } \\
\text { bodies of } \\
\text { Executive } \\
\text { power }\end{array}$ & $\begin{array}{l}\text { National } \\
\text { security } \\
\text { concept of } \\
\text { the } \\
\text { Republic } \\
\text { of Belarus }\end{array}$ \\
\hline
\end{tabular}

Source: elaboration of author.

Strategic national interests of the Republic of Belarus in the sphere of social and economic security can be combined into 3 main vectors:

-long-term stable financial and economic growth at a rate surpass the global average and the European rate of increase in GDP;

-improving the competitiveness of the economy of the state and its economic entities, the conquest of fresh niches in the commodity and money markets;

-the growth of welfare and life of the population, the conquest of the position of Belarus in the global cultural space. 
The study of internal and external dangers of socio-economic security showed that the dangers cannot be manifested in a clear and acute form for a long time, which should not weaken the interest in solving certain tasks, which are indicated by indicators of socio-economic security.

The development of hazards into decline is due to ineffective management decisions and an increase in the number of hazards. The more experts and researchers notice the dangers of socioeconomic security and the more communication and interaction between these dangers, the more likely the decline.

A special role in the formation of the centers of decline in the modern world belongs not to the cycles of capital renewal and not even to the cycles of technology renewal, but to the cycles of accumulation of finances and failures in the functioning of markets. In the criteria of globalization, the busiest instruments of the market are subject to unimaginable risks. As a result, exchange rates, price conditions, guidelines for the behavior of traders and the top management, the reliability of control methods and procedures have a decisive impact on the economic situation and socioeconomic security of the country.

Indicators of socio-economic security are considered, first of all, financial and economic characteristics: 1) correctly reflecting the essence of the dangers of socio-economic security; 2) possessing greater variability and in this regard a greater opportunity to warn society, government and market participants about the likely dangers due to the change in the macroeconomic situation; 3 ) interacting with each other to the necessary extent.

The thresholds of social and economic security are considered to be the limits, ignoring of which hinders the normal development of the economy and the public sphere and leads to the formation of destructive consequences in the production and living standards of the population.

\section{References:}

1. Shvaiba D. Dynamic regression models of forecasting indicators of social and economic security // Бюллетень науки и практики. 2019. Т. 5. №1. С. 249-257.

2. Shvaiba D. Industry of the Republic of Belarus: problems of social and economic security // Бюллетень науки и практики. 2018. Т. 4. №9. С. 245-252.

\section{Список литературы:}

1. Shvaiba, D. (2019). Dynamic regression models of forecasting indicators of social and economic security. Bulletin of Science and Practice, 5(1), 249-257.

2. Shvaiba, D. (2018). Industry of the Republic of Belarus: problems of social and economic security. Bulletin of Science and Practice, 4(9), 245-252.

Работа поступила

в редакцию 16.09.2019 г.
Принята к публикаџии

22.09.2019 2.

\section{Ссылка для цุитирования:}

Shvaiba D. Research of Indicator Analysis of Social and Economic Security // Бюллетень науки и практики. 2019. Т. 5. №10. C. 128-132. https://doi.org/10.33619/2414-2948/47/17

Cite as (APA):

Shvaiba, D. (2019). Research of Indicator Analysis of Social and Economic Security. Bulletin of Science and Practice, 5(10), 128-132. https://doi.org/10.33619/2414-2948/47/17 (in Russian). 